\title{
Gender-Specific Effects on Immune Response and Cardiac Function after Trauma Hemorrhage and Sepsis
}

\author{
Markus Albertsmeier $^{\mathrm{a}} \quad$ Sebastian Pratschke $^{\mathrm{a}} \quad$ Irshad Chaudry $^{\mathrm{b}} \quad$ Martin K. Angele $^{\mathrm{a}}$ \\ ${ }^{a}$ Department of General, Visceral, Transplantation, Vascular and Thoracic Surgery, Ludwig Maximilian University, Munich, Germany \\ ${ }^{b}$ Center for Surgical Research and Department of Surgery, University of Alabama at Birmingham, Birmingham, AL, USA
}

\section{Keywords}

Gender · Sex steroids · Hemorrhagic shock ·

Immune depression - Immune modulation

\section{Summary}

Background: Studies in human as well as animal models indicate a gender-specific responsiveness of the immune and organ systems with regard to shock, trauma, and sepsis. Methods: A literature review was performed. Results: Cell-mediated immune responses and cardiovascular functions are suppressed in males following trauma hemorrhage, whereas they are maintained or even enhanced in females in the proestrus state of the estrus cycle. Experimental studies have demonstrated that divergent immune responses in males and females following adverse circulatory conditions are mediated by the gender-specific hormones testosterone and estrogen. Several clinical trials, however, failed to demonstrate a significant association of gender and inflammatory response. This may be explained by the heterogeneity of the population in terms of their hormonal status at the time of injury. Conclusions: With regard to the underlying mechanisms, receptors for sex hormones have been identified on various immune cells, suggesting direct effects of these hormones on immune function. Alternatively, indirect effects of sex steroids such as changes in cardiovascular responses or androgen- and estrogen-synthesizing enzymes might contribute to gender-specific immune responses. Clinical studies suggest that sex hormones, such as dehydroepiandrosterone, modulate the function of peripheral blood mononuclear cells also following abdominal surgery. Thus, sex hormones, receptor antagonists, and sex steroid-synthesizing enzymes might be useful in the future for modulating the complex immune responses after trauma hemorrhage and sepsis.

The first two authors contributed equally to this work.

\author{
Schlüsselwörter \\ Geschlecht · Geschlechtshormone · Hämorrhagischer \\ Schock · Immunsuppression · Immunmodulation
}

\section{Zusammenfassung}

Hintergrund: Klinische wie auch experimentelle Studien zeigen eine geschlechtsspezifische Antwort der Immunund Organsysteme gegenüber Trauma, Schock und Sepsis. Methoden: Eine Literaturübersicht wurde durchgeführt. Ergebnisse: Die zelluläre Immunantwort und die kardiovaskuläre Funktion sind nach einem Blutungsschock bei männlichen Patienten supprimiert, während sie bei Frauen in der Proöstrus-Phase erhalten oder sogar verbessert sind. Experimentelle Studien haben gezeigt, dass die Immunantwort auf kardiozirkulatorische Schockzustände durch die Geschlechtshormone Testosteron und Östrogen beeinflusst wird. Andererseits konnten mehrere klinische Studien eine solche Abhängigkeit der Inflammationsprozesse vom Geschlecht nicht nachvollziehen. Dies kann durch die Heterogenität der Population bezüglich des hormonellen Status zum Zeitpunkt des Traumas erklärt werden. Schlussfolgerungen: Was die zugrunde liegenden Mechanismen angeht, so wurden Rezeptoren für $\mathrm{Ge}$ schlechtshormone auf unterschiedlichen Immunzellen gefunden, was direkte Effekte dieser Hormone auf die Immunzellen nahelegt. Alternativ könnten indirekte Effekte der Sexualhomone wie z.B. Veränderungen der kardiovaskulären Funktion oder androgen- und östrogensynthetisierender Enzyme zu einer geschlechtsspezifischen Immunantwort beitragen. Klinische Studien zeigen, dass Geschlechtshormone wie z.B. Dehydroepiandrosteron die Funktion mononukleärer Zellen auch nach abdominalchirurgischen Eingriffen modulieren. Geschlechtshormone, Rezeptorantagonisten und geschlechtshormonsynthetisierende Enzyme könnten daher in Zukunft dazu genutzt werden, die Immunfunktion nach hämorrhagischem Schock oder in der Sepsis zu beeinflussen.

\begin{tabular}{ll}
\hline KARGER & ( 2014 S. Karger GmbH, Freiburg \\
1662-6664/14/0302-0091\$39.50/0 \\
Fax+497614520714 \\
$\begin{array}{l}\text { Information@Karger.com } \\
\text { www.karger.com }\end{array}$ & $\begin{array}{l}\text { Accessible online at: } \\
\text { www.karger.com/vim }\end{array}$
\end{tabular}

Prof. Dr. med. Martin K. Angele

Department of General, Visceral, Transplantation, Vascular and Thoracic Surgery Ludwig-Maximilian University Munich

Marchioninistraße 15, 81377 Munich, Germany

Martin.Angele@med.uni-muenchen.de 


\section{Introduction}

Differences between women and men can be identified at many levels of the immune response, and may affect its outcome. Clinical and experimental studies have demonstrated gender-specific humoral and cell-mediated immune responses (fig. 1). For example, the incidence of autoimmune diseases, such as systemic lupus erythematosus (SLE) (female to male ratio of 9:1), Hashimoto's thyroiditis, rheumatoid arthritis, and primary biliary cirrhosis, differs significantly between the sexes [1-4]. Moreover, higher levels of circulating plasma antibodies have been found in females with autoimmune disease compared to male patients [5]. While it is plausible that some sex-linked genes may contribute to the genetic predisposition for autoimmune disease processes, other likely culprits for this gender bias are male and female sex hormones [2, 6]. Administration of testosterone in female F1 NZB/NZW mice, for example, prevented the development of lupus erythematosus [7]. Further support for the notion that male and female sex steroids differently affect autoimmune disease processes comes from studies showing lower androgen levels and increased levels of active estrogen metabolites in women with SLE compared to age-matched healthy female controls $[8,9]$. In addition, not only humoral but also cell-mediated immune responses appear to exhibit sexual dimorphism. As early as 1898, Calzolari [10] reported a connection between reproduction and immunology when he found the thymus of rabbits castrated before sexual maturity to be larger than that of male controls. Moreover, a shorter skin allograft rejection time has been reported in females compared to males [11]. The aforementioned studies demonstrate that male and female sex steroids modulate humoral and cell-mediated immune functions and thereby affect several disease processes. In this regard, gender has also been identified as an important factor in the human body's response to injury and sepsis: in a huge series of 681,000 patients utilizing the US National Trauma Data Bank, Haider et al. [12] demonstrated a significantly lower mortality as well as a decreased complication rate in female compared to male trauma patients. Male trauma patients also have a higher risk for the development of sepsis and multiple organ failure [13-16] and a significantly lower survival rate (31 vs. $74 \%$ ) in sepsis [17].

This article will review the epidemiological and clinical data published on this subject, and discuss why some clinical studies failed to demonstrate a difference between the two sexes in the response to trauma hemorrhage and sepsis. Pathophysiological findings that may explain sexual dimorphism are described, and based on these findings novel therapeutic approaches targeted at the influence of sex hormones on the immune response to injury and sepsis are presented. To this end, a MEDLINE search was performed using the terms (sex hormones OR gender) AND (shock OR trauma OR hemorrhage OR sepsis). Experimental studies in animals as well as clinical trials and retrospective analyses were in- cluded if they examined the influence of either gender or sex hormones on survival or other applicable outcome parameters in one or more of the following clinical situations or experimental models thereof: cardiocirculatory shock, severe trauma, hemorrhage, or sepsis. Redundant studies were excluded, and additional explanatory evidence was included as deemed necessary by the authors.

\section{Clinical Evidence for Gender Differences in Trauma, Shock, and Sepsis}

An analysis of the National Trauma Data Bank, comprising more than 150,000 patients involved in blunt and penetrating trauma, observed an association between gender and mortality among blunt trauma patients, especially those aged $\geq 50$ years $[18,19]$, while other studies concluded that female gender was not associated with decreased mortality if patients were adequately stratified in a multivariate analysis considering independent risk factors, including the injury severity score (ISS) or patient age [20] (table 1).

Offner et al. [21] studied 545 trauma patients older than 15 years with an ISS higher than 15 and prospectively detected those with survival of more than $48 \mathrm{~h}$. They revealed that male gender was associated with significantly increased risk of severe infectious complications after trauma, and this correlation was most significant following injuries of moderate severity. Gender differences in B and T lymphocyte function, $\mathrm{T}$ helper cell counts, and natural killer cell counts have been hypothesized as mechanisms on a cellular and molecular level [22]. Furthermore, increased serum interleukin(IL)-6 and procalcitonin levels in male compared to female patients have been suggested as humoral mechanisms [23].

Sepsis syndrome is a manifestation of an acute infection and is characterized by a generalized inflammatory response [13]. In an experimental ex vivo setting of septic shock, when peripheral blood mononuclear cells (PBMC) were incubated with lipopolysaccharide (LPS), the release of tumor necrosis factor(TNF)- $\alpha$ from these cells after $6 \mathrm{~h}$ was significantly higher in samples of healthy males compared to that from female volunteers [24]. This increased cytokine release capacity in male patients was also observed after blunt injuries with an ISS $\geq 16$, and was additionally associated with an increased susceptibility to sepsis compared to female trauma victims [23]. Coyle et al. [25] prospectively evaluated the effects of intravenous application of LPS in 72 healthy volunteers (48 male, 24 female), and found increased core temperature and decreased mean arterial blood pressure in men compared with woman. However, no differences were observed regarding host immune responses to LPS (white blood cell count, cortisol or cytokine level) between males and females.

Although several clinical trials indicated gender-specific differences in clinical outcome after trauma, animal studies, in which the experimental conditions are generally better con- 
Table 1. Multi-institutional studies on the outcome of trauma patients depending on gender

\begin{tabular}{lllrll}
\hline Study, year [ref.] & $\begin{array}{l}\text { Age group, } \\
\text { years }\end{array}$ & ISS & $\mathrm{n}$ & $\begin{array}{l}\text { Mortality rate } \\
\text { male vs. female }\end{array}$ & $\mathrm{p}$ \\
\hline Morris et. al., 1990 [78] & all & all & 199,737 & - & n.s. \\
& $\geq 40$ & $\leq 25$ & - & RR : 0.7-2.0 & $<0.05$ \\
Wohltmann et al., 2001 [79] & all & all & 20,261 & 8 vs. 7\% & n.s. \\
& $<50$ & all & 15,839 & 7 vs. 5\% & $<0.002$ \\
Gannon et al., 2002 [20] & $<50$ & $\geq 25$ & 2,138 & 33 vs. 25\% & $<0.026$ \\
George et al., 2003 [18] & $\geq 20$ & all & 22,332 & 7 vs. 5\% & n.s. \\
\hline
\end{tabular}

${ }^{\text {a }}$ Relative risk of mortality for males.

n.s. $=$ Not significant.

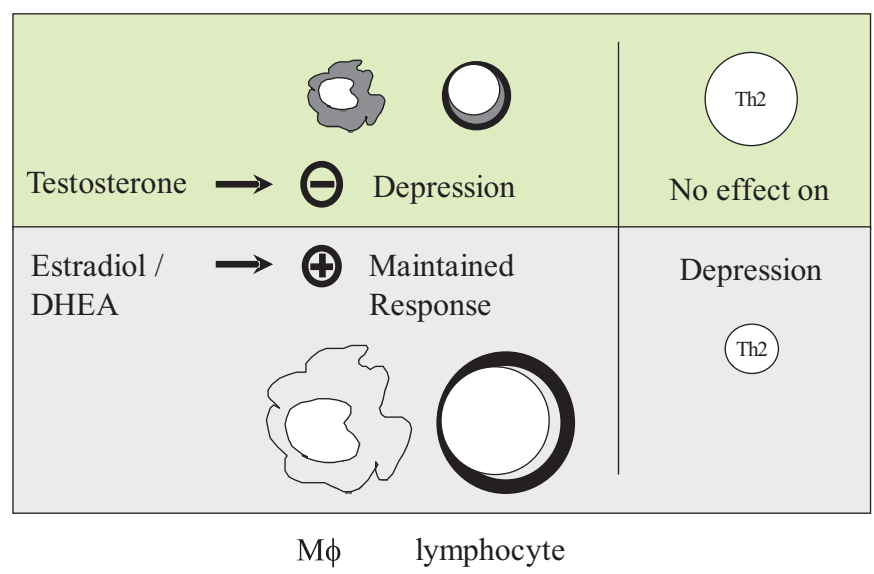

Fig. 1. Schematic illustration of the effect of gender on cell-mediated immune responses following trauma and severe blood loss.

trolled, mostly revealed more pronounced gender-specific alterations. One widely accepted explanation for contradictory or less convincing evidence for the influence of gender in injury and sepsis in some patient studies is the heterogeneity of the population studied in relation to their hormonal state [18].

\section{Gender-Specific Effects on Immune Function after Experimental Trauma Hemorrhage and Sepsis}

Several experimental studies have shown that immune functions are depressed in males as well as ovariectomized and aged females after trauma hemorrhage and sepsis, and remain depressed despite fluid resuscitation $[14,26]$. In this respect, female rats showed a higher resistance towards disturbances of the microcirculation following trauma or intestinal ischemia [27]. Moreover, proestrus female mice exhibit increased levels of proinflammatory Th1 lymphokines, such as IL-2 or interferon(IFN)- $\gamma$, compared to male mice following trauma hemorrhage [28]. On the other hand, anti-inflammatory Th2 lymphokines, such as IL-10, are decreased in females compared to males after trauma hemorrhage [29]. A gender-dependent immune response has also been described in experimental models of sepsis with survival rates of females significantly higher than those of males (60 vs. $25 \%$ ) [30]. One explanation for the observation that females are more resistant towards septic challenges may be an increased early expression of inflammatory cytokines such as IL-1 [31]. Interestingly, the immune response to trauma and hemorrhage in females depends on the hormonal status at the time of injury: a more pronounced immune reaction is found during proestrus as compared to diestrus, potentially corresponding with enhanced levels of estrogen and pregnenolone [26, 32, 33]. In clinical studies, the maximum expression of proinflammatory cytokines has been observed in the follicular phase of the menstrual cycle [34-36]. Sex-specific immune reactions have also been shown in the thymus, at the location of $\mathrm{T}$ cell lymphopoiesis $[37,38]$. In female mice, thymocytes and lymphocytes show an enhanced reaction to antigens compared to thymocytes and lymphocytes from male mice [38], and a reduced apoptosis rate in models of trauma and hemorrhage, respectively [37]. An increased apoptotic rate in males may represent an attempt to decrease autoreactive T cells after trauma and hemorrhage [39]. With respect to sex hormones, studies in castrated mice that develop SLE [40] showed that the application of androgens delayed the onset of SLE. Interestingly, thymectomy abolished the protective effects of administered androgens on the induction of SLE [40]. Nevertheless, the relevance of some of these studies is narrowed by limitations of their study design; in older trials, mainly young male animals were utilized. More recent studies on shock and trauma also took into account the effects of age, gender, and sex hormones, showing advantages for young female animals. Further studies are required to clarify whether these advantages in morbidity and mortality might be neutralized in older female animals to the level of aged males.

\section{Gender-Specific Effects on Cardiovascular Function under Stressful Conditions}

After trauma hemorrhage, an impaired cardiac performance has been observed in male animals, leading to a generalized organ hypoperfusion [41, 42]. In this respect, cardiovascular and hepatic function was reduced in males and estrus females, but not in proestrus females, following trauma and 
Table 2. Experimental results on the effect of sex steroids and gender following trauma, shock, and sepsis

\begin{tabular}{|c|c|c|}
\hline & \multicolumn{2}{|l|}{ Effect of trauma, shock, and sepsis } \\
\hline & males & females (proestrus) \\
\hline Mortality after sepsis & $70 \%$ (in mice after CLP) & $20 \%$ (in mice after CLP) \\
\hline Effect of sex hormone depletion & castration: immunoprotective & ovariectomy: immunosuppressive \\
\hline Treatment option & $\begin{array}{l}\text { flutamide (testosterone receptor antagonist) } \\
\text { estrogen } \\
\text { DHEA (via estrogen receptor) }\end{array}$ & $\begin{array}{l}\text { estrogen (in non-proestrus females) } \\
\text { DHEA }\end{array}$ \\
\hline
\end{tabular}

$\mathrm{CLP}=$ Cecal ligation and puncture.

resuscitation [43]. Interestingly, studies showed that castration of male rats 2 weeks before the induction of trauma hemorrhage led to maintenance of myocardial function [44]. Estradiol, on the other hand, has been found to improve cardiovascular and hepatic function following cardiocirculatory shock $[28,45]$. As a potential mechanism, an increased blood volume in females following trauma hemorrhage could explain the observed gender specificities in immune and organ functions [46]. A study analyzing regional myocardial contractile function in a magnetic resonance imaging-based multiparametric strain analysis indicated that there is a significantly larger circumferential and longitudinal left ventricular strain in normal female volunteers, indicating a better functional cardiac reserve in women [47]. Similarly, Sarikouch et al. [48] observed increased end-diastolic and end-systolic left ventricular volumes in female patients and decreased biventricular ejection fractions in males late after repair of tetralogy of Fallot. The exact underlying mechanism remains unclear, nonetheless, and should be further investigated.

\section{The Role of Gender-Specific Hormones in Trauma Hemorrhage and Sepsis}

Gender-specific immune reactions are regulated on a hormonal level. The responsible hormones are mainly released from the gonads, and secondarily from the thymus and the hypothalamus and the pituitary glands (table 2) [49-55]. In experimental trauma hemorrhage, prior castration and depletion of male sex hormones increased the release of splenic and peritoneal macrophage cytokines [51, 53-56]). Interestingly, preconditioning of female mice with 5-dihydrotestosterone (DHT) over 2 weeks before trauma hemorrhage caused a reduction in splenic and peritoneal macrophage function similar to males [50,51]. In contrast, female sex steroids exhibit an increase in cell-mediated immune reactions [57-59]. Elevated systemic levels in proestrus females play a pivotal role in the immunocompetence following trauma hemorrhage [58] maintained by splenocytes and splenic macrophages [60, 61]. Moreover, application of $17 \beta$-estradiol was associated with a significantly increased survival rate in sepsis [61]. Although Sperry et al. [62] failed to show differences between pre- and postmenopausal human females after injury and hemorrhagic shock, the protective role of female sex steroids is further underlined by experimental data indicating an increased mortality in trauma hemorrhage and sepsis after ovariectomy [58]. In conclusion, estrogen seems to play a pivotal role in the immunocompetence of females following trauma hemorrhage. Therefore, the application of female sex hormones in ovariectomized or postmenopausal female patients could be beneficial for the therapy of immunodeficiency under such conditions.

\section{Immune Modulation by Sex Steroids and Subsequent Therapeutic Properties}

Immune-modulating properties of sex steroids have been shown in vitro: thymocytes from hemorrhaged animals incubated with DHT exhibited reduced expression of IL-3 but an increased apoptotic rate [36], while peritoneal macrophages showed an enhanced release of TNF when co-incubated with estradiol [63]. These immunomodulatory effects could be explained by the presence of estrogen receptors on immune cells, such as thymocytes, macrophages, and leukocytes [2, 64]. Recently another cell surface receptor, G protein-coupled receptor(GPR)-30, has been described to bind estrogen [65, 66].

Furthermore, altered synthesis of sex steroids is evident after trauma hemorrhage $[67,68]$. Physiological plasma testosterone levels are associated with an impaired cellular immune defense [50-52, 55]. After trauma hemorrhage, however, an even enhanced DHT synthesis has been shown in male $\mathrm{T}$ lymphocytes. In contrast, in proestrus females an increased synthesis and a decreased catabolism of estradiol can be found in the T lymphocytes [67, 68]. 
Endogenous testosterone impairs the immune response and organ function following trauma and blood loss. In this respect, the usage of the androgen receptor antagonist flutamide has been examined with regard to immune response in models of trauma and severe bleeding. Flutamide is frequently used for testicular cancer over prolonged periods, and no major adverse effects have been reported. Following trauma hemorrhage and resuscitation, the immune response was significantly increased as indicated by enhanced expression of cytokines from macrophages due to the administration of flutamide [69]. Moreover, in sepsis after trauma hemorrhage, the application of flutamide over 3 days also improved the release of cytokines from splenic macrophages, and significantly reduced mortality [70]. Therefore, the short-term use of this androgen receptor antagonist in male trauma patients could represent a new treatment for deleterious immunodeficiency as well as cardiovascular dysfunction in trauma and sepsis.

The steroid hormone dehydroepiandrosterone (DHEA) is a precursor for estrogen and testosterone, and is found in abundance in the plasma of both females and males. In males, DHEA and its metabolites develop mainly estrogenic effects [71]. On the basis of the beneficial effects of estrogen shown in trauma hemorrhage, DHEA and its metabolite androstenetriol have been applied in animal models of trauma hemor- rhage and sepsis, leading to enhanced cellular immune responses and increased survival rates [72-74]. These effects are in part mediated by natural killer cells which represent one group of effector cells for the protective properties of DHEA [75]. Interestingly, DHEA also improved the inflammatory cytokine response of human PBMC in vitro, which is normally suppressed after major abdominal surgery [76]. Therefore, DHEA could play a salutary role in female and male trauma victims by reducing mortality through an enhanced cellular immune response.

A recent study revealed improved survival in males, but not in females, following trauma hemorrhage due to the application of IL-10, which underlines the clinical relevance of immunmodulatory therapies [77]. Nonetheless, the exact underlying mechanisms of the connection between gender, sex hormones, and the immune system are not yet fully clarified. Therefore, further experimental as well as prospective clinical trials must be performed to develop therapies against detrimental immunosuppressive conditions after trauma hemorrhage and sepsis.

\section{Disclosure Statement}

The authors state they have no conflict of interest to declare.

\section{References}

$>_{1}$ Roubinian JR, Talal N, Greenspan JS, Goodman JR, Siiteri PK: Effect of castration and sex hormone treatment on survival, anti-nucleic acid antibodies, and glomerulonephritis in NZB/NZW F1 mice. J Exp Med 1978;147:1568-1583.

2 Olsen NJ, Kovacs WJ: Gonadal steroids and immunity. Endocr Rev 1996;17:369-384.

3 Hochberg MC, Spector TD: Epidemiology of rheumatoid arthritis: update. Epidemiol Rev 1990;12: 247-252.

4 Sherlock S, Scheuer PJ: The presentation and diagnosis of 100 patients with primary biliary cirrhosis. N Engl J Med 1973;289:674-678.

5 Franks CR, Letter: Hormone exposure and lymphocytic impairment. JAMA 1975;232:19-20.

6 Grimaldi CM, Hill L, Xu X, Peeva E, Diamond B: Hormonal modulation of B cell development and repertoire selection. Mol Immunol 2005;42:811-820.

7 Roubinian JR, Talal N, Greenspan JS, Goodman JR, Siiteri PK: Delayed androgen treatment prolongs survival in murine lupus. J Clin Invest 1979; 63:902-911.

8 Lahita RG, Bradlow HL, Fishman J, Kunkel HG: Abnormal estrogen and androgen metabolism in the human with systemic lupus erythematosus. Am J Kidney Dis 1982;2:206-211.

9 Lahita RG, Bradlow HL, Ginzler E, Pang S, New M: Low plasma androgens in women with systemic lupus erythematosus. Arthritis Rheum 1987;30:241-248.

10 Calzolari A: Recherches experimentales sur un rapport probable entre la function du thymus et celle des testicules. Arch Ital Biol 1898;30:71-77.
11 Graff RJ, Lappe MA, Snell GD: The influence of the gonads and adrenal glands on the immune response to skin grafts. Transplantation 1969;7:105-111.

12 Haider AH, Crompton JG, Oyetunji T, et al: Females have fewer complications and lower mortality following trauma than similarly injured males: a risk adjusted analysis of adults in the National Trauma Data Bank. Surgery 2009;146:308-315.

13 Bone RC: Toward an epidemiology and natural history of SIRS (systemic inflammatory response syndrome). JAMA 1992;268:3452-3455.

14 Angele MK, Schwacha MG, Ayala A, Chaudry IH: Effect of gender and sex hormones on immune responses following shock. Shock 2000;14:81-90.

15 Kong LB, Lekawa M, Navarro RA, et al: Pedestrian-motor vehicle trauma: an analysis of injury profiles by age. J Am Coll Surg 1996;182:17-23.

16 Kher A, Wang M, Tsai BM, et al: Sex differences in the myocardial inflammatory response to acute injury. Shock 2005;23:1-10.

17 Schroder J, Kahlke V, Staubach KH, Zabel P, Stuber F: Gender differences in human sepsis. Arch Surg 1998;133:1200-1205.

18 George RL, McGwin G Jr, Metzger J, Chaudry IH, Rue LW 3rd: The association between gender and mortality among trauma patients as modified by age. J Trauma 2003;54:464-471.

19 George RL, McGwin G Jr, Windham ST, et al: Age-related gender differential in outcome after blunt or penetrating trauma. Shock 2003;19:28-32.

20 Gannon CJ, Napolitano LM, Pasquale M, Tracy JK, McCarter RJ: A statewide population-based study of gender differences in trauma: validation of a prior single-institution study. J Am Coll Surg 2002;195:11-18.
21 Offner PJ, Moore EE, Biffl WL: Male gender is a risk factor for major infections after surgery. Arch Surg 1999;134:935-938.

22 Wichmann MW, Muller C, Meyer G, et al: Different immune responses to abdominal surgery in men and women. Langenbecks Arch Surg 2003:387:397-401.

23 Majetschak M, Christensen B, Obertacke U, et al: Sex differences in posttraumatic cytokine release of endotoxin-stimulated whole blood: relationship to the development of severe sepsis. J Trauma 2000;48:832-839.

24 Asai K, Hiki N, Mimura Y, Ogawa T, Unou K, Kaminishi M: Gender differences in cytokine secretion by human peripheral blood mononuclear cells: role of estrogen in modulating LPS-induced cytokine secretion in an ex vivo septic model. Shock 2001;16:340-343.

25 Coyle SM, Calvano SE, Lowry SF: Gender influences in vivo human responses to endotoxin. Shock 2006;26:538-543.

26 Ananthakrishnan P, Cohen DB, Xu DZ, Lu Q, Feketeova E, Deitch EA: Sex hormones modulate distant organ injury in both a trauma/hemorrhagic shock model and a burn model. Surgery 2005;137: $56-65$.

27 Altura BM: Sex and estrogens in protection against circulatory stress reactions. Am J Physiol 1976;231: 842-847.

28 Wichmann MW, Zellweger R, DeMaso CM, Ayala A, Chaudry IH: Enhanced immune responses in females as opposed to decreased responses in males following hemorrhagic shock. Cytokine 1996;8:853-863. 
29 Kahlke V, Angele MK, Ayala A, et al: Immune dysfunction following trauma-hemorrhage: influence of gender and age. Cytokine 2000;12:69-77.

-30 Zellweger R, Wichmann MW, Ayala A, Stein S, DeMaso CM, Chaudry IH: Females in proestrus state maintain splenic immune functions and tolerate sepsis better than males. Crit Care Med 1997; 25:106-110.

$31 \mathrm{Li}$ P, Allen H, Banerjee S, et al: Mice deficient in IL-1b-converting enzyme are defective in production of mature IL-1b and resistant to endotoxic shock. Cell 1995;80:401-411.

-32 Krzych U, Strausser HR, Bressler JP, Goldstein AL: Effects of sex hormones on some $\mathrm{T}$ and $\mathrm{B}$ cell functions, evidenced by differential immune expression between male and female mice and cyclic pattern of immune responsiveness during the estrous cycle in female mice. Am J Reprod Immunol 1981;1:73-77.

\$3 Krzych U, Strausser HR, Bressler JP, Goldstein AL: Quantitative differences in immune responses during various stages of the estrous cycle in female BALB/c mice. J Immunol 1978;121:1603-1605.

34 Baron RL: Pathophysiology of septic shock and implications for therapy. Clin Pharm 1998;12:829845.

\$3 Hu SK, Mitcho YL, Rath NC: Effect of estradiol on interleukin-1 synthesis by macrophages. Int J Immunopharmacol 1988;10:247-252.

-36 Cannon JG, Dinarello CA: Increased plasma interleukin-1 activity in women after ovulation. Science 1985;227:1247-1249.

37 Angele MK, Xu YX, Ayala A, et al: Gender dimorphism in trauma-hemorrhage-induced thymocyte apoptosis. Shock 1999;12:316-322.

38 Weinstein Y, Ran S, Segal S: Sex-associated differences in the regulation of immune responses controlled by the MHC of the mouse. J Immunol 1984; 132:656-661.

39 Janeway CA Jr: How the immune system discriminates infectious nonself from noninfectious self; in Faist E, Meakins J, Schildberg FW (eds): Host Defense Dysfunction in Trauma, Shock and Sepsis. Berlin/Heidelberg, Springer, 1993, pp 39-47.

40 Sheridan PJ: Can a single androgen receptor fill the bill? Mol Cell Endocrinol 1991;76:C39-C45.

41 Wang P, Hauptman JG, Chaudry IH: Hemorrhage produces depression in microvascular blood flow which persists despite fluid resuscitation. Circ Shock 1990;32:307-318.

42 Wang P, Ba ZF, Burkhardt J, Chaudry IH: Traumahemorrhage and resuscitation in the mouse: effects on cardiac output and organ blood flow. Am J Physiol 1993;264:H1166-H1173.

43 Jarrar D, Wang P, Cioffi WG, Bland KI, Chaudry $\mathrm{IH}$ : The female reproductive cycle is an important variable in the response to trauma-hemorrhage. Am J Physiol 2000;279:H1015-H1021.

44 Remmers DE, Bland KI, Cioffi WG, Wang P, Angele MK, Chaudry IH: Testosterone: the crucial hormone responsible for depressing myocardial function in males after trauma-hemorrhage. Ann Surg 1998;227:790-799.

45 Mizushima Y, Wang P, Jarrar D, Cioffi WG, Bland KI, Chaudry IH: Estradiol administration after trauma-hemorrhage improves cardiovascular and hepatocellular functions in male animals. Ann Surg 2000;232:673-679.

46 Kuebler JF, Toth B, Rue LW, III, Wang P, Bland KI, Chaudry IH: Differential fluid regulation during and after soft tissue trauma and hemorrhagic shock in males and proestrus females. Shock 2003; 20:144-148.
47 Lawton JS, Cupps BP, Knutsen AK, et al: Magnetic resonance imaging detects significant sex differences in human myocardial strain. Biomed Eng Online 2011;10:76.

48 Sarikouch S, Koerperich H, Dubowy KO, et al; German Competence Network for Congenital Heart Defects Investigators: Impact of gender and age on cardiovascular function late after repair of tetralogy of Fallot: percentiles based on cardiac magnetic resonance. Circ Cardiovasc Imaging 2011;4:703-711.

49 Grossman CJ: Possible underlying mechanisms of sexual dimorphism in the immune response, fact and hypothesis. J Steroid Biochem 1989;34:241-251.

50 Angele MK, Ayala A, Monfils BA, Cioffi WG, Bland KI, Chaudry IH: Testosterone and/or low estradiol: normally required but harmful immunologically for males after trauma-hemorrhage. J Trauma 1998;44:78-85.

51 Angele MK, Ayala A, Cioffi WG, Bland KI, Chaudry IH: Testosterone: the culprit for producing splenocyte depression following trauma-hemorrhage. Am J Physiol 1998;274:C1530-C1536.

52 Angele MK, Knoferl MW, Schwacha MG, et al: Sex steroids regulate pro- and antiinflammatory cytokine release by macrophages after trauma-hemorrhage. Am J Physiol 1999;277:C35-C42.

53 Zellweger R, Zhu X-H, Wichmann MW, Ayala A, DeMaso CM, Chaudry IH: Prolactin administration following hemorrhagic shock improves macrophage cytokine release capacity and decreases mortality from subsequent sepsis. J Immunol 1996; 157:5748-5754.

54 Wichmann MW, Ayala A, Chaudry I: Male sex steroids are responsible for depressing macrophage immune function after trauma-hemorrhage. Am J Physiol 1997;273:C1335-C1340.

55 Angele MK, Knoferl MW, Ayala A, Bland KI, Chaudry IH: Testosterone and estrogen differently effect Th1 and Th2 cytokine release following trauma-haemorrhage. Cytokine 2001;16:22-30.

56 Wichmann MW, Zellweger R, DeMaso CM, Ayala A, Chaudry IH: Mechanism of immunosuppression in males following trauma-hemorrhage: critical role of testosterone. Arch Surg 1996;131:1186-1192.

57 Friedman D, Netti F, Schreiber AD: Effect of estradiol and steroid analogues on the clearance of immunoglobulin G-coated erythrocytes. J Clin Invest $1985 ; 75: 162-167$.

58 Knoferl MW, Angele MK, Schwacha MG, Bland KI, Chaudry IH: Preservation of splenic immune functions by female sex hormones after traumahemorrhage. Crit Care Med 2002;30:888-893.

59 Yamamoto Y, Saito H, Setogawa T, Tomioka H: Sex differences in host resistance to mycobacterium marinum infection in mice. Infect Immun 1991;59:4089-4096.

60 Knoferl MW, Jarrar D, Angele MK, et al: 17 betaestradiol normalizes immune responses in ovariectomized females after trauma-hemorrhage. Am J Physiol Cell Physiol 2001;281:C1131-C1138.

61 Knoferl MW, Diodato MD, Angele MK, et al: Do female sex steroids adversely or beneficially affect the depressed immune responses in males after trauma-hemorrhage? Arch Surg 2000;135:425-433.

62 Sperry JL, Nathens AB, Frankel HL, et al; Inflammation and the Host Response to Injury Investigators: Characterization of the gender dimorphism after injury and hemorrhagic shock: are hormonal differences responsible? Crit Care Med 2008;36:1838-1845.

63 Chao TC, VanAlten PJ, Greager JA, Walter RJ: Steroid sex hormones regulate the release of tumor necrosis factor by macrophages. Cell Immunol 1995;160:43-49.
64 Cutolo M, Sulli A, Seriolo B, Accardo S, Masi AT: Estrogens, the immune response and autoimmunity. Clin Exp Rheum 1995;13:217-226.

65 Filardo EJ, Thomas P: GPR30: a seven-transmembrane-spanning estrogen receptor that triggers EGF release. Trends Endocrinol Metab 2005;16:362-367.

66 Revankar CM, Cimino DF, Sklar LA, Arterburn JB, Prossnitz ER: A transmembrane intracellular estrogen receptor mediates rapid cell signaling. Science 2005;307:1625-1630.

67 Samy TS, Knoferl MW, Zheng R, Schwacha MG, Bland KI, Chaudry IH: Divergent immune responses in male and female mice after trauma-hemorrhage: dimorphic alterations in $\mathrm{T}$ lymphocyte steroidogenic enzyme activities. Endocrinology 2001;142:3519-3529.

68 Zheng R, Samy TS, Schneider CP, Rue LW, Bland KI, Chaudry IH: Decreased 5alpha-dihydrotestosterone catabolism suppresses $\mathrm{T}$ lymphocyte functions in males after trauma-hemorrhage. Am J Physiol Cell Physiol 2002;282:C1332-C1338.

69 Wichmann MW, Angele MK, Ayala A, Cioffi WG, Chaudry I: Flutamide: a novel agent for restoring the depressed cell-mediated immunity following soft-tissue trauma and hemorrhagic shock. Shock 1997;8:1-7.

70 Angele MK, Wichmann MW, Ayala A, Cioffi WG, Chaudry IH: Testosterone receptor blockade after hemorrhage in males: restoration of the depressed immune functions and improved survival following subsequent sepsis. Arch Surg 1997;132:1207-1214.

71 Ebeling P, Koivisto VA: Physiological importance of dehydroepiandrosterone. Lancet 1994;343:1479_ 1481

72 Angele MK, Catania RA, Ayala A, Cioffi WG, Bland K, Chaudry IH: Dehydroepiandrosterone (DHEA): an inexpensive steroid hormone which decreases the mortality from sepsis. Arch Surg 1998;133:1281-1288.

73 Catania RA, Angele MK, Ayala A, Cioffi WG, Bland K, Chaudry IH: Dehydroepiandrosterone (DHEA) restores immune function following trauma-hemorrhage by a direct effect on T-lymphocytes. Cytokine 1998;11:443-450.

74 Marcu AC, Paccione KE, Barbee RW, et al: Androstenetriol immunomodulation improves survival in a severe trauma hemorrhage shock model. J Trauma 2007;63:662-669.

75 Zeckey C, Hildebrand F, Hoevel P, et al: Activity of lymphocyte subpopulations in polymicrobial sepsis and DHEA treatment in IL-6 knockout mice. J Innate Immun 2010;2:469-477.

76 Frantz MC, Prix NJ, Wichmann MW, et al: Dehydroepiandrosterone (DHEA) restores the depressed PBMC function following major abdominal surgery via the estrogen receptors. Crit Care Med 2005;33:1779-1786.

77 Kahlke V, Dohm C, Mees T, Brotzmann K, Schreiber S, Schroder J: Early interleukin-10 treatment improves survival and enhances immune function only in males after hemorrhage and subsequent sepsis. Shock 2002;18:24-28.

78 Morris JA Jr, MacKenzie EJ, et al: Mortality in trauma patients: the interaction between host factors and severity. J Trauma 1990;30:1476-1482.

79 Wohltmann CD, Franklin GA, et al: A multicenter evaluation of whether gender dimorphism affects survival after trauma. Am J Surg 2001;181:297-300. 